\title{
Instytucja rodziny w teologii Pawłowej i Bizancjum w opiniach sądów cerkiewnych Despotatu Epiru
}

\author{
archimandryta Andrzej Borkowski \\ Katedra Teologii Prawosławnej \\ Uniwersytet w Białymstoku \\ Polska \\ borkowskiunath@yahoo.gr
}

\begin{abstract}
Fr. Andrzej Borkowski, The Institution of the Family in Pauline theology and Byzantium in Despotat Epirus's Church Court Opinions, Elpis, 18 2016: 37-44.

Abstract: St Paul teaches that family life is founded on the union of a man and woman, which symbolises the relation between Christ and His Church. A second guideline to family life is the education and upbringing of children "in Christ." The Apostle Paul, in his letters provides parents with advice on how they should raise their children, and children on how they should behave in relation to their parents. In this advice, although limited in number and extend, one can distinguish the basic elements of Christian education for children. For the Apostle Paul, the cultivation of healthy relations is indispensable, not only in the relations between husbands and wives, but also in the relationship between parents and children. Parents have the main responsibility for the creation of pedagogic relation with their children and they can contribute to their education, by providing them social stimuli. The institution of the family has long attracted the interest of Byzantine scholars. Influenced by, among other things, the social sciences, the focus has expanded in recent years to include the function of the family as a social and economic unit in Byzantine society. Since marriage is the basis for the formation of a family, the field of study embraces the rules governing the contracting of a marriage (age, criteria for the selection of a spouse), betrothal, impediments to marriage, the institution of marriage portions and bridal gifts, the status of the wife and children, divorce and so on. Under the Romans, marriage was a civil act. As Christianity spread, the Church gradually came to intervene and acquire a role in the institution. The purpose of marriage is procreation and the perpetuation of the human race, and in this sense, it is of interest to both church and state. A turning-point was reached with the promulgation by Leo VI the Wise (886-912) of Novella 89, which laid down that only marriages blessed by the Church were legal. Later statues, beginning with the Tome (997) of Patriarch Sisinnius, codified the impediments to marriage by reason of kinship or affinity. Among the most illuminating sources for the study of the family and the legal relations deriving from marriage are the decisions and opinions of the ecclesiastical courts of the principality of Epirus and specifically those of the Metropolitan, John Apokaukos, and the Archdiocese of Ochrid, under Demetrios Chomatenos. It is interesting to note that these two prelates considered the cases brought before them not only in the light of the secular law and Church rules, but also with a certain broadness of mind and social sensitivity.
\end{abstract}

\begin{abstract}
Streszczenie: Św. Paweł naucza, że życie rodzinne opiera się na związku mężczyzny i kobiety, które symbolizuje związek między Chrystusem i Jego Cerkwią. Drugą wskazówką życia rodzinnego jest edukacja i wychowanie dzieci „w Chrystusie”. Apostoł Paweł w swoich listach udziela rodzicom rad, w jaki sposób należy wychowywać swoje dzieci, a dzieciom, jak powinni się zachowywać wobec swoich rodziców. W tych zaleceniach można wyróżnić podstawowe elementy edukacji chrześcijańskiej dzieci. Dla apostoła Pawła zachowanie zdrowych relacji jest niezbędne nie tylko w stosunkach między małżonkami, ale także w relacjach między rodzicami i dziećmi. Rodzice ponoszą główną odpowiedzialność za tworzenie pedagogicznych relacji z dziećmi i mogą przyczynić się do ich edukacji, poprzez dostarczanie im właściwych bodźców społecznych. Instytucja rodziny od dawna przyciąga zainteresowanie uczonych bizantyjskich. Pod wpływem - między innymi - nauk społecznych, w ostatnich latach położono szczególny nacisk na funkcję rodziny jako jednostki społecznej i ekonomicznej w społeczeństwie bizantyńskim. Ponieważ małżeństwo jest podstawą do tworzenia rodziny, omawiany obszar badawczy obejmuje przepisy regulujące zawieranie małżeństw (wiek, kryteria wyboru małżonka), zaręczyn, przeszkód do zawarcia małżeństwa, instytucji posagu, statusu żony i dzieci, rozwodów, itd. U Rzymian, małżeństwo było aktem cywilnym. W miarę rozprzestrzeniania się chrześcijaństwa, Cerkiew stopniowo zajmowała stanowisko odnośnie tej instytucji. Celem małżeństwa jest prokreacja i utrwalenie rasy ludzkiej, pod tym względem jest przedmiotem zainteresowania zarówno Cerkwi i państwa. Istotny punkt zwrotny został osiągnięty przez Leona VI Mądrego (886-912), który uznał małżeństwo pobłogosławione przez Cerkiew za jedyne legalne. Później, poczynając od Tomosu (997) patriarchy Sysaniusza, skodyfikowano przeszkody do zawarcia małżeństwa z powodu pokrewieństwa lub powinowactwa. Ważnymi źródłami do badań nad rodziną i stosunkami prawnymi wynikającymi z małżeństwa są decyzje i opinie sądów cerkiewnych Despotatu Epiru, a zwłaszcza te należące do biskupów Jana Apokaukosa i Demetriosa Chomatenosa.
\end{abstract}

Keywords: family, marriage, the Byzantine, Orthodox judiciary

Słowa kluczowe: rodzina, małżeństwo, Bizancjum, sądownictwo cerkiewne

Rodzina jest naturalnym środowiskiem i pierwszą instytucją wychowania wpływającą na dzieci socjalizująco, stwarzającą warunki do rozwoju lub hamujące go. Wywiera ważny wpływ na zachowanie się jednostek, relacje międzyludzkie, ich stosunek do świata wartości chrześcijańskich. Rodzina określana jest, jako podstawowa grupa społeczna, instytucja wychowawcza, środowisko wychowawcze, środowisko kulturowe i jako wspólnota ${ }^{1}$.

S. Kawula, J. Brągiel, A. W. Janke, Pedagogika rodziny. Obszary i panorama problematyki, Toruń 1998, s. 26. L. Dyczewski, Rodzina - społeczeństwo - państwo, [w:] Rodzina w okresie transformacji systemowej, red. A. Kurzynowski, Suwałki - Warszawa 1995. Dziecko potrzebujace pomocy. 
Na kryzys rodziny w współczesnej Europie, zagrażający jej tradycyjnej strukturze, składają się następujące powody: Rozluźnienie więzi między członkami rodziny, przeniesienie zawarcia związku małżeńskiego na coraz bardziej starszy wiek, problemy ze stabilizacją zawodową nowożeńców, uporczywość kobiet na tle realizacji kariery zawodowej, zniesienie zróżnicowania ról w rodzinie, wolne związki przedmałżeńskie, odsakralnienie związku małżeńskiego, prawo do natychmiastowego rozwodu, odkarnienie cudzołóstwa, osiągnięcia medycyny w genetyce i inne².

Jeśli nawet kryzys instytucji rodziny w ostatnich latach coraz bardziej zatrważa i niepokoi, to jednak Cerkiew ze swą teologią małżeństwa i życia rodzinnego wskazuję na właściwy jej wymiar. Od początku istnienia wykazuje dużą troskę wobec związku kobiety i mężczyzny. Już od epoki Starego Testamentu podkreśla się: „Dlatego opuści mąż ojca swego i matkę swoją i złączy się z żoną swoją, i staną się jednym ciałem” (Rdz. 2.24). Apostoł narodów Paweł dużo później zaznaczy, że przez związek mężczyzny i kobiety symbolicznie ukazane zostały relacje Chrystusa i Cerkwi ${ }^{3}$. W społeczności chrześcijańskiej z epoki apostoła Pawła miłość Chrystusa do Cerkwi przedstawiana jest, jako wzór miłości małżeńskiej, która w jej imię sięga aż do przynoszenia w ofierze własnego życia. Zatem pierwszym i głównym fundamentem rodziny, zgodnie z listem do Efezjan $(5,22-33)$ jest bezinteresowna miłość i ofiarność, której będzie towarzyszyła odnawiająca i oczyszczająca siła miłości, twórcza zgoda, ale także wzajemne poszanowanie między małżonkami.

Jedność mężczyzny i kobiety w epoce Starego Testamentu jest nierozerwalnie związana z prokreacją, ale równocześnie traktowane jest, jako błogosławieństwo Boże 4 . Pan Bóg poleca prarodzicom „Rozradzajcie się i rozmnażajcie się, i napełniajcie ziemię" (Rdz. 1,28). Św. Jan Chryzostom w komentarzu do Księgi Rodzaju nadmienia, że somatyczny związek małżonków nie jest wystarczający do

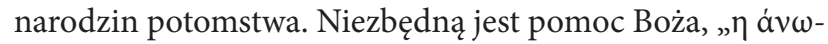

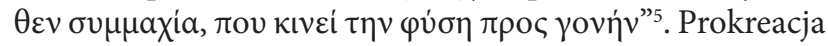
jest rezultatem miłości małżonków oraz cudownym darem od Boga człowiekowi. Równocześnie staje się środkiem do zbawienia wówczas, gdy składa się zgodnie z nauką Pawłową z „wiary, miłości i uświęcenia” (I Tym. 2, 15). Dlatego Cerkiew podkreśla, że małżonkowie powinni poznawać teologiczną i duchową wartość prokreacji, aby zrozumieli,

Możliwości, kierunki, formy wsparcia wśrodowisku lokalnym, red. J. Izdebska, Suwałki - Warszawa 2003, s. 7. A. Przecławska, Relacje między ludźmi jako przedmiot badań pedagogicznych, Warszawa 1993. K. Ferenz, Wprowadzenie dzieci w kulture, Wrocław 1993. A. Janke, Wychowanie rodzinne - kluczowe pojęcie pedagogicznych rozważan nad rodzina, [w:] Wychowanie w kontekście teoretycznym, red. A. Tchorzewski, Bydgoszcz 1993.

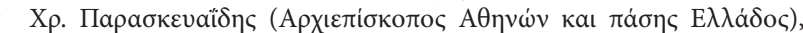

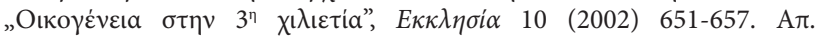

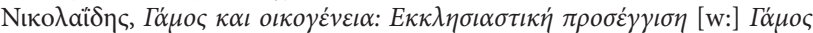

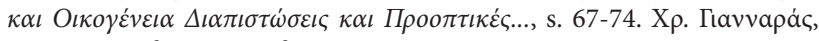

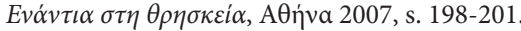

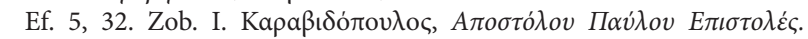

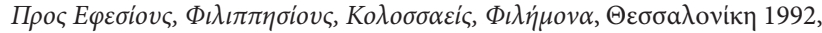
s. 213.

4 Por. Rdz. 16, Pwt. 25,5-10, Oz. 9,11, I Krl. 1.

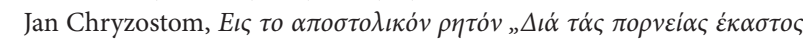

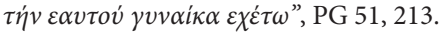

tak jak to celnie zauważa św. Klemens Aleksandryjski, że rodząc dzieci przynoszą na świat ikony Boga ${ }^{6}$.

Drugim filarem rodziny w epoce Pawłowej jest „, $\varepsilon v \mathrm{X} \rho-$ $\sigma \tau \omega^{\prime \prime}$ oświata i wychowanie dzieci . Jeśli nawet są nam znane role mężczyzny - ojca, kobiety - matki i dziecka tym nie mniej czynione są starania umocnienia relacji poszczególnych osób w liturgiczną jedność w duchu wzajemnego szacunku. Jeśli nawet nie są dosłownie naśladowane wzorce tradycyjnego społeczeństwa akcentujące absolutną władzę ojca, całkowite podporządkowanie żony mężowi oraz pełne posłuszeństwo dzieci wobec rodziców, w liście do Kolosan (3, 20-21) znajdujemy jasną zachętę „Dzieci, bądźcie posłuszne rodzicom we wszystkim; albowiem Pan ma w tym upodobanie. Ojcowie, nie rozgoryczajcie dzieci swoich, aby nie upadały na duchu"s. To jednak dla apostoła Pawła ale także dla całej teologii prawosławnej manifest z listu do Galatów „Nie masz Żyda ani Greka, nie masz niewolnika ani wolnego, nie masz mężczyzny ani kobiety; albowiem wy wszyscy jedno jesteście w Jezusie Chrystusie" $(3,28)$ stanowi oś oraz odpowiedź na postawione zagadnienie w kwestii kształtowania się relacji miedzy członkami Cerkwi ale także społeczeństwa każdej epoki.

Apostoł Paweł kierując się, jak sam to określa, jako oj-

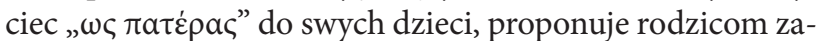
chowanie, które powinni zaadoptować w stosunku do swego potomstwa, mianowicie wprowadzić w życie analogiczne pojęcie o ojcostwie Boga i ojcowskich relacjach z Jego dziećmi, tj. ludźmi. Pomimo że w listach apostolskich nie znajdujemy sformułowania systematycznej teorii pedagogicznej o wychowaniu dzieci w rodzinie, to jednak istnieją liczne fragmenty, np. I Kor. 4,14-16, I Tes. 2,7-11, I Tym. 5,1-2, Gal. 4,19, Hebr. 12,5-7, 12,9-11, w których pośrednio lub bezpośrednio udziela pedagogicznych porad i zachęt dotyczących relacji rodziców i dzieci w rodzinie. Dzięki nim możemy wyłonić zasadnicze elementy, które rekomendują pewien określony typ wychowania chrześcijańskiego, czyniąc tym samym z apostoła Pawła charyzmatycznego pedagoga.

Odnośnie relacji dzieci z rodzicami ${ }^{9}$ zachęca, aby kie-

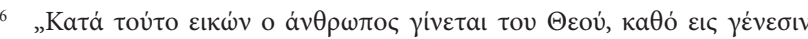

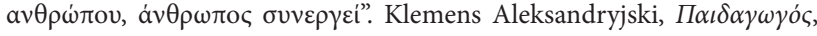
PG 10,83,2-5.

„Wychowanie rodzinne spełnia się poprzez silną więź osobowa między rodzicami i dziećmi, wyrażającą się między innymi w odpowiedzialności za drugiego człowieka; we wzajemnych spotkaniach, w relacjach przepojonych miłością, troską mądrością i doświadczeniem starszych. Dziecko w różnych okresach swego życia pozostaje pod wpływem silnych wychowawczych oddziaływań rodziny. Ta wyjątkowość i specyfika oddziaływań wychowawczych w rodzinie sprawia, że rodzina jest dla dziecka pierwszym i podstawowym, najważniejszym miejscem rozwoju, edukacji, zaspokojenia potrzeb ludzkich oraz potrzeb fizjologicznych. Warunki i atmosfera, jaką tworzy rodzina, jako wspólnota, wzmacnia proces wychowania rodzinnego, proces rozwoju młodego człowieka”. B. KrzesińskaŻach, Pedagogika rodziny, Białystok 2007, s. 21.

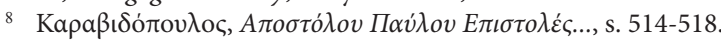

9 „Relacje rodzinne - dotyczą różnorodnych sytuacji życiowych, w których zachodzą wzajemne stosunki pomiędzy członkami w najbliższym środowisku życia - rodzinie... Relacje między dzieckiem a rodzicami mogą mięć charakter relacji jednostronnych lub wzajemnych interakcji, które prowadzą do pozytywnych, korzystnych zmian w dziecku, w rodzinie, w grupie rówieśniczej, do wzbogacenia treści i charakteru samych relacji... Dobrze funkcjonujący związek małżeński dostarcza jego uczestnikom dwóch podstawowych form wsparcia - emocjonalnego i instrumentalnego - w pełnieniu roli rodzica. Emocjonalne wsparcie jest komunika-
} 
rowali się posłuszeństwem „Dzieci, bądźcie posłuszne rodzicom swoim w Panu, bo to rzecz słuszna" (Ef. 6,1) następnie dodaje „Czcij ojca swego i matkę, to jest pierwsze przykazanie $\mathrm{z}$ obietnicą: Aby ci się dobrze działo i abyś długo żył na ziemi” (6, 2-3), natomiast w liście do Kolosan radzi „Dzieci, bądźcie posłuszne rodzicom we wszystkim; albowiem Pan ma w tym upodobanie" $(3,20)$. Jest oczywistym, że w przytoczonych fragmentach apostoł stosuje te same słowa, aby zaakcentować wobec dzieci obowiązek posłuszeństwa w stosunku do rodziców. W ówczesnej epoce dzieci znajdowały się pod absolutną władzą ojca, który posiadał wszelkie prawo do stosowania surowych $\operatorname{kar}^{10}$. Chrześcijaństwo przyczyniło się przede wszystkim do wyniesienia miejsca dziecka $\mathrm{w}$ rodzinie oraz uwydatnienia jego praw tak, aby dziś zajmowało centralne miejsce w wychowaniu z zabezpieczonymi ustawodawczo prawami.

Ze względu na młody wiek, dzieci nie są w stanie zrozumieć wartości i intencji zastosowania dyscypliny. Wydaje się im, że jest ograniczana ich wolność wobec tego czują niezadowolenie „Żadne karanie nie wydaje się chwilowo przyjemne, lecz bolesne, później jednak wydaje błogi owoc sprawiedliwości tym, którzy przez nie zostali wyćwiczeni" (Hebr. 12,11). Dziecko, czym bardziej zbliża się do wieku dojrzałego zaczyna co raz lepiej rozumieć i uszanować wartość dyscypliny oraz powody zastosowania przez rodziców. Zastosowanie dyscypliny może być ułatwione, gdy dziecko rozumie, że jest konsekwencją miłości rodziców, pragnących pomóc mu stać sie lepszym, oraz gdy jest stosowana w klimacie dialogu, miłości, wzajemnego szacunku bez strachu i groźby kary ${ }^{11}$. Apostoł Paweł wzywa dzieci do posłuszeństwa wobec rodzi-

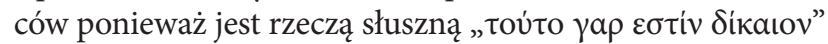
(Ef. 6, 1). Koreluje posłuszeństwo dzieci z pojęciem sprawiedliwości, nie w sensie prawniczym, ale jako prawego, prawidłowego, zgodnego, odzwierciedlając tym samym pojęcia danej epoki zgodnie, $\mathrm{z}$ którym było prawidłowym, aby dzieci podporząalkowały się władzy swych rodziców ${ }^{12}$.

Zachęta dzieci do posłuszeństwa rodzicom w liście do Efezjan $(6,2-3)$ opiera się na przykazaniu Dekalogu „Czcij ojca swego i matkę swoją, aby długo trwały twoje dni w ziemi, którą Pan, Bóg twój, da tobie" (Wj. 20,12, Pwt. 27,16), w którym została zawarta obietnica, czczącym swych rodziców, bowiem doznają szczęścia, długowieczności i błogosławieństwa Bożego ${ }^{13}$. Poprzez dodatkowa frazę

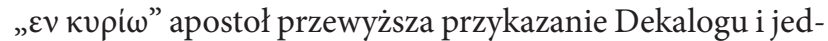
nocześnie wprowadza i ugruntowuje posłuszeństwo dzieci jako wola Pana, czyn podobający sie Bogu „albowiem Pan ma w tym upodobanie" (Kol. 3,20). Apostoł Paweł odnosi sie do posłuszeństwa w rodzinie chrześcijańskiej, w której polecenia rodzicielskie nie przekraczają prawa Chrystusa.

tem dla małżonka - rodzica, że jest kochany, szanowany i ceniony, a to $\mathrm{z}$ kolei wpływa na stopień zaangażowania i cierpliwości, którą rodzic wnosi do relacji z dzieckiem", B. Krzesińska-Żach, Pedagogika rodziny, s. 15-16.

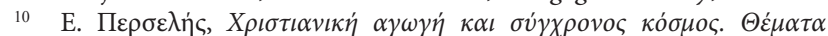

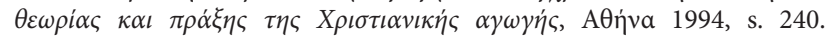

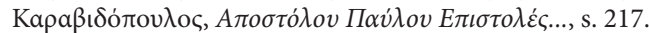

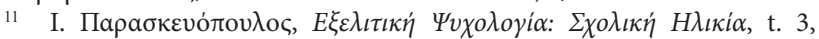
AӨñva 1985, s. 100,104,108,113.

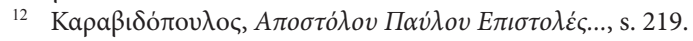

13 Ibidem.
Pragnie podkreślić znaczenie owego przykazania dzieciom, aby zrozumiały, że ich rodzice są obarczeni odpowiedzial-

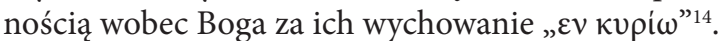

W kwestii relacji rodziców do dzieci apostoł Paweł radzi im jak maja zachowywać się wobec swych dzieci "A wy, ojcowie, nie pobudzajcie do gniewu dzieci swoich, lecz napominajcie i wychowujcie je w karności, dla Pana" (Ef. 6,4) podobnie pisze w liście do Kolosan „Ojcowie, nie rozgoryczajcie dzieci swoich, aby nie upadały na duchu" $(3,21)$. Czyni to z zamiarem podkreślenia, iż do stworzenia harmonijnego związku w rodzinie nie wystarczy wyłącznie szacunek dzieci do rodziców, ale także analogiczne relacje rodziców w stosunku do swych dzieci. Dlatego zaleca w szczególności ojcom ${ }^{15}$, aby nie rozdrażniali czułej i delikatnej struktury psychicznej dziecka. Do stworzenia właściwej atmosfery w rodzinie niezbędnym jest rozumny dialog w duchu łagodności i napomnień „Piszę to, nie aby was zawstydzić, lecz aby was napomnieć, jako moje dzieci umiłowane" (I Kor. 4,14). Dialektyczni rodzice, którzy przysposabiają formę dialogu, współpracy i wewnętrznej samodyscypliny, stwarzają wokół siebie otoczenie, w którym króluje szacunek w stosunku do innej osoby, poszanowanie praw osobistych, swobodnej woli, wolności słowa ${ }^{16}$. $\mathrm{W}$ takim otoczeniu dziecko czuje się istotnym i aktywnym członkiem rodzinnego życia i buduje poczucie samooceny i autonomii. Rodzice z samokontrolą mogą nauczać ich dziecko jak zapanować nad stanami gniewu i agresji1".

Gdy rodzice srogo karzą swe dzieci, wywołują o u nich silny wewnętrzny gniew i wzburzenie, które przejawia się jeszcze większą agresją, w ten sposób tworząc błędne koło. Kara stawia sobie za cel ukierunkowanie dziecka ku bardziej pożądanemu zachowaniu, „Bo kogo Pan miłuje, tego karze, I chłoszcze każdego syna, którego przyjmuje. Jeśli znosicie karanie, to Bóg obchodzi się z wami jak z synami; bo gdzie jest syn, którego by ojciec nie karał?" (Hebr. 12,6-7). Niezwykle istotnym jest aby rodzice objaśniali swym dzieciom negatywne konsekwencje ich działań na uczucia innych osób, a nie poszukiwania jedynie ucieczki od nich. Znajomość konsekwencji czynów na innych umożliwia u dziecka rozwiniecie się wewnętrznej dyscypliny oraz przeciwstawienie się niepożądanym zachowaniom. Nakładanie kary bez należytego wyjaśnienia nie przynosi pożądanych rezultatów bez dania alternatywnego sposobu uniknięcia gniewu za pomocą innej przyjętej metody wyrazu np. przebaczenia. Całkowite tolerowanie przez rodziców agresji wśród dzieci, bez zastosowania jakiejkolwiek próby dyscypliny, nie przynosi pożądanych rezultatów, ponieważ agresja pozostawiona samej sobie rodzi agresję ${ }^{18}$.

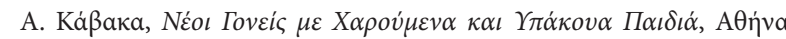
1985 , s. 165

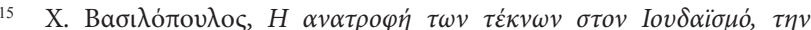

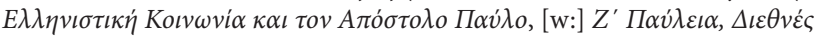

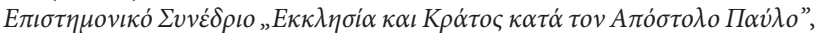
Bépota 2001, s. 108.

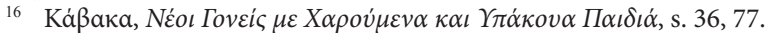

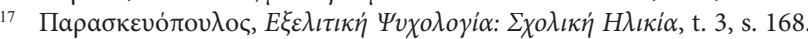

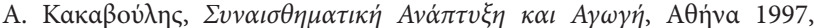
s. 171-172.

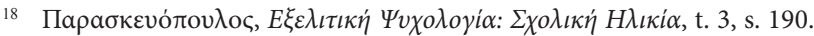


W przeciwieństwie do antropocentrycznego charakteru w starożytnej Helladzie i nomocentrycznego w judaizmie, społeczeństwo Pawłowe naśladuje chrystocentryczny charakter wychowania dzieci. W epoce Pawłowej jest akcentowane zróżnicowanie liturgiczne poszczególnych członków rodziny, niezbędne do właściwego funkcjonowania, zaś osią rodziny jest zawsze chrystocentryczna struktura Cerkwi postrzegana, jako Ciało Chrystusowe. Tak, więc w liście do Efezjan we fragmencie mówiącym o wzajemnych obowiązkach i relacjach rodziców i dzieci (Ef. 6, 1-4), Apostoł w ogólnym zarysie proponuje, aby wychowanie dzieci odbywało się zgodnie z wolą Bożą i było identyfikowane $\mathrm{z}$ przykazaniem miłości. $\mathrm{Z}$ tego względu Cerkiew w modlitwach z sakramentu ślubu mówi o sztuce

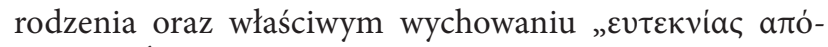
$\lambda a v \sigma v{ }^{\prime}$. Św. Jan Chryzostom komentuje to w następują-

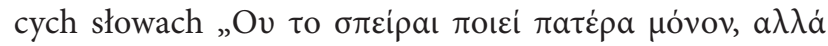

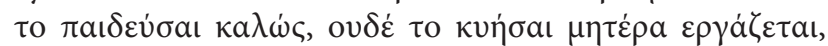

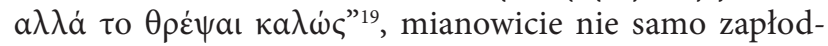
nienie czyni z mężczyzny ojca, ale prawidłowe wychowanie dziecka, ani z faktu donoszenia ciąży matkę, ale troska o jego właściwy rozwój.

Apostoł umieszcza relacje rodziców do dzieci w ramach „عv Kupíw”, tj. miłości chrześcijańskiej. Zachęca rodziców do wychowywania dzieci „ojcowie... napominajcie i wychowujcie je w karności, dla Pana”(Ef. 6,4) zgodnie z wolą Bożą objawioną światu przez Jezusa Chrystusa. Egzegeci przytaczają, że "pouczenie” dotyczy wychowania w słowach (tj. zgodnie ze słowami i przykazaniami Pańskimi) natomiast „oświata” polega na wychowaniu w czynach (tj. z pomocą przykazania miłości) i nie koniecznie z zastosowaniem kar. Zatem miłość (chrześcijańska, rodzicielska) winna stanowić czynnik regulujący relacje między członkami rodziny oraz zachowanie rodziców w stosunku do swych dzieci ${ }^{20}$. Słowem „kupíov” Paweł wynosi pedagogiczne dzieło rodziców do przykładu wzoru najwyższego pedagoga Pana naszego Jezusa Chrystusa i tym samym wprowadza chrystocentryczny charakter wychowania w rodzinie ${ }^{21}$.

Apostoł Pawel, duchowy ojciec swych dzieci, chrześcijan, „pouczając” naucza pedagogicznej teorii i praktyki w rodzinie. Rodzina stanowi u Pawła naturalne otoczenie gdzie kładzie się podstawy i fundamenty formacji osobowości ludzkiej. Zatem rodzice ponoszą główną odpowiedzialność za stworzenie atmosfery relacji pedagogicznych $\mathrm{z}$ ich dziećmi i w konsekwencji osobowość rodziców i ich dojrzałość duchowa istotnie wpływają na rozwój wspólnotowości u dzieci. Relacje między dziećmi i rodzicami, w całym okresie rozwoju dziecięcego, stanowi jedną z najbardziej ważnych stron osobistego i towarzyskiego życia człowieka ${ }^{22}$.

Instytucja rodziny od dawna skupiała zainteresowanie badaczy Bizancjum poczynając od konstruowania drzew genealogicznych, pisania prosopograficznych opracowań słynnych rodzin, które odegrały protagonistyczną rolę

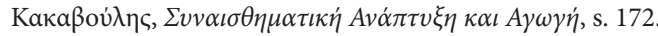

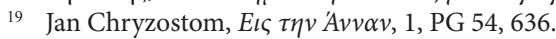

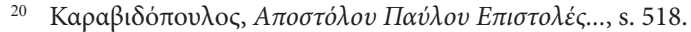

21 Ibidem, s. 219.

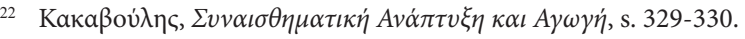

w polityce, a dzięki przemyślanym związkom małżeńskim umacniały swą pozycję dochodząc nawet do cesarskiego tronu. Ostatnimi laty pod wpływem nauk społecznych badania zwróciły się w stronę postrzegania instytucji rodziny, jako pierwotnej społecznej i ekonomicznej monady oraz życia codziennego ludzi. Naukowców zaintrygował sposób stworzenia, struktury i funkcjonowania rodziny w społeczeństwie bizantyjskim, rola kobiety i dzieci, więzi rodzinne, związki małżeńskie, rozwody, itp.

Ustawodawstwo cesarskie oraz kanony cerkiewne, teksty historyków i chronografów, pisma patrystyczne i hagiolologiczne, postanowienia sądowe sądów świeckich i cerkiewnych, ale także dzieła literackie podają nam informacje odnośnie tego tematu. Afigimatyczne źródła, które zwykle odgrywały ważne miejsce w rodzinach wyższej grupy socjalnej, w rezultacie zepchnęły na margines, pozostawiając poza kręgiem zainteresowań naukowców rodzinę średniej i niższej klasy. W powyższej sytuacji szczególnie odkrywczymi wydają się pozostawać postanowienia i opinie sądów cerkiewnych państwa Epiru, powstałego po zajęciu Konstantynopola przez Franków z IV wyprawy krzyżowej w 1204 roku² ${ }^{23}$ Przytoczę kilka przykładów werdyktów sądów cerkiewnych z metropolii Naupaktos, której arcypasterzem był wykształcony hierarcha Jan Apokaukos oraz arcybiskupstwa Ochrydy z hierarchą Demetriuszem Chomatenosem, gdyż stanowią doskonałe świadectwo stosowanych ówcześnie w praktyce praw ${ }^{24}$. Ich teksty są niezwykle cenne, ponieważ odkrywają różne aspekty z życia na terytorium Epiru, warunków egzystencji, relacji międzyludzkich, zachowań władcy, możnych, duchowieństwa, ale także kontaktów zwykłych obywateli państwa ${ }^{25}$.

Ponieważ małżeństwo stanowi podstawę do formowania rodziny, przytoczę pokrótce kanony zajmujące się zawarciem związku małżeńskiego (wiekiem, kryteriami wyboru przyszłej pary nowożeńców), narzeczeństwem, przeszkodami małżeństwa, instytucją posagu i ślubnych darów pana młodego, rozwodu ${ }^{26}$.

Małżeństwo w epoce rzymskiej było czynnością polityczną. W Bizancjum, we wschodniej części cesarstwa rzymskiego, pojawia się stopniowo rola i wpływ Cerkwi, która wytycza kanony instytucji małżeństwa oraz życiu erotycznemu młodych, określa przeszkody małżeńskie nie tylko ze względów więzi krwi czy zbyt bliskiego pokrewieństwa, ale również $\mathrm{z}$ powodu duchowego powinowactwa, nakłada kary ze względu na różne wykroczenia. Określonymi celami małżeństwa, tj. prokreacją i przedłużeniem rodu

\footnotetext{
23 Zob. Świat Bizancjum, t. 3, Bizancjum i jego sąsiedzi 1204-1453, red. A. Laiou, C. Morrisson, s. 343-355.

24 A. Znosko, Prawosławne prawo kościelne, Warszawa 1973, s. 73.

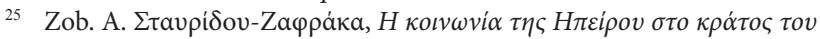

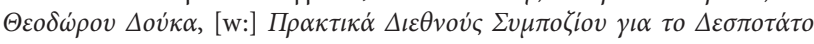

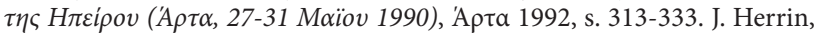
Bizancjum. Niezwykłe dziedzictwo średniowiecznego imperium, Poznań 2010, s. 105-106.

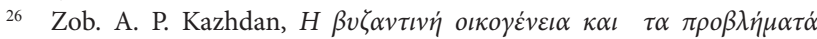

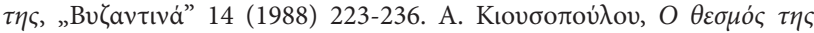

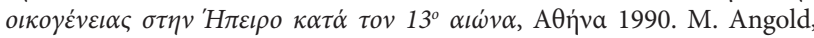

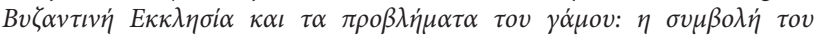

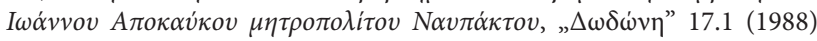
179-194.
} 
ludzkiego, zainteresowane są zarówno Państwo jak Cerkiew.

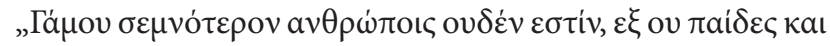

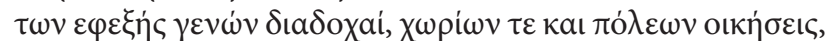

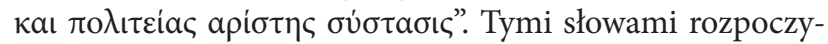

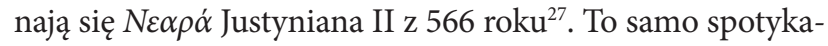

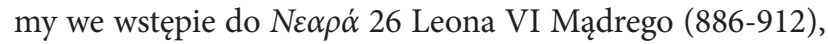
czytamy: „Małżeństwo jest wielkim i cennym darem Boga i Twórcy ludzkości. Nie tylko pomaga naturze z jej skłonnością do zepsucia i śmiertelności, ale także przyczynia się do zachowania rodu (ludzkiego), skoro nie dopuszcza do jego całkowitego zaprzepaszczenia..., ale ...wyświadcza wielkie dobrodziejstwo życiu ludzkiemu za pośrednictwem rodze-

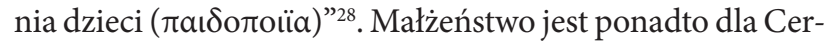

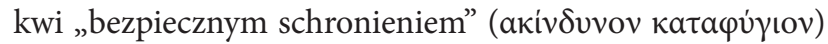
pozwalającym na uniknięcie rozwiązłości w przypadku nierozumnego bezżeństwa, jak charakterystycznie wyraża się Demetriusz Chomatenos na podstawie znanego fragmentu z listu Apostoła Pawła (I Kor. 7, 8-9) ${ }^{29}$. Podobnie czyni Jan Apokaukos, który zsyła się opiniodawczo na apostoła naro-

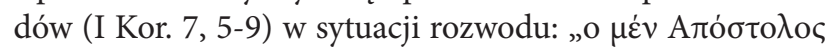

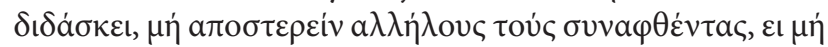

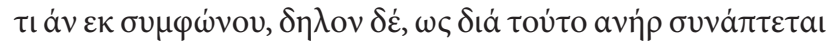

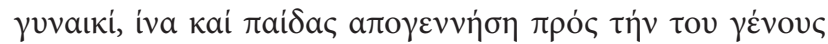

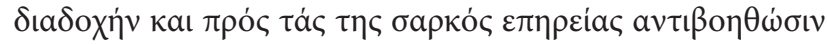

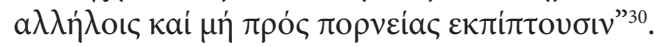

W kanonach 53 i 54 Piąto-szóstego Soboru Powszechnego w Trullo z 662 roku zostały między innymi określone przeszkody małżeńskie ze względu na więzi krwi, ale także pokrewieństwa duchowego, np. ojciec chrzestny nie może poślubić wdowy matki ochrzczonego dziecka ${ }^{31}$. Powyższe przeszkody zostały także uprawomocnione przez państwo w Eklodze Izauryjczyków z marca 741 roku, w której małżeństwo staje się czynnością polityczną zawartą za pośrednictwem zgody nowożeńców i ich rodziców. Zostaje

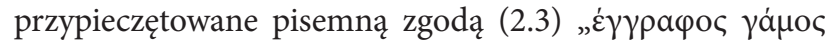

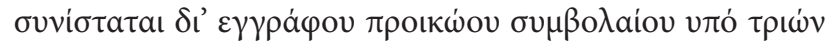

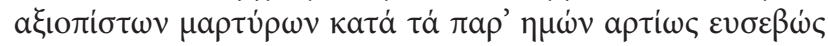

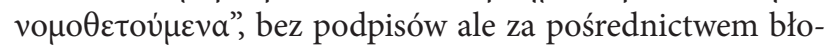

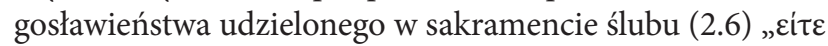

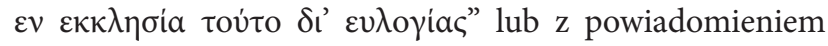
przyjaciół bądź najzwyklejszego współżycia ${ }^{32}$. Znaczący etap stanowią $N \varepsilon \alpha \rho \alpha ́$ 89 Leona VI, w której małżeństwem pociągającym za sobą prawomocne rezultaty jest wyłącznie

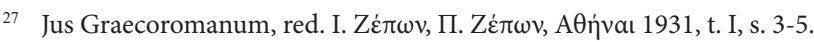

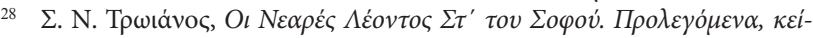

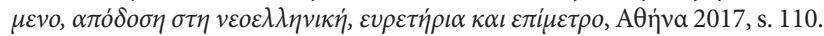

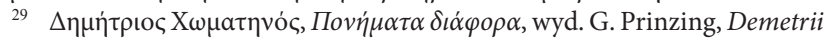
Chomateni Ponemata diaphora [CFHB 38, Series Berolinensis], BeroliniNovi Eboraci 2002, nr. 30.10-12.

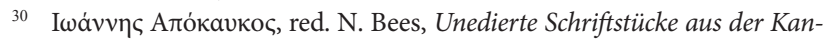
zlei des Johannes Apokaukos des Metropoliten von Naupaktos (in Aetolien), „Byzantinisch-Neugriechische Jahrbücher” 21 (1971/76) 57-160, nr 28, 89.7-14.

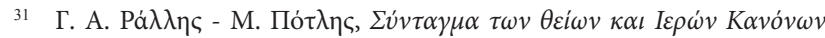

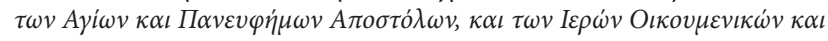

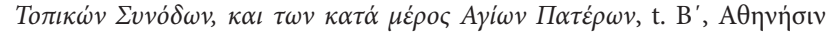
1852, s. 428-429, 432.

32 Ecloga. Das Gesetzbuch Leons III. und Konstantinos' V. Herausgegeben von L. Burgmann [Forschungen zur Byzantinischen Rechtsgeschichte 10] 2.3 , s. $172 ; 2.6$, s. 178 .
}

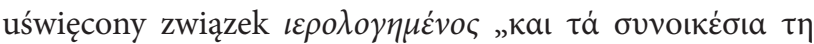

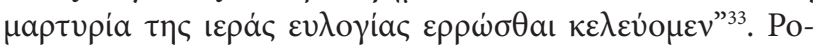
wyższy fakt wiązał się z formalnym nałożeniem na Cerkiew prawnego obowiązku zatwierdzania wszystkich małżeństw. Małżeństwo cywilne zniknęło, jako akt prawny, zastąpiony obowiązkiem małżeństwa cerkiewnego. Jedynymi ważnymi małżeństwami są od tej pory związki zgodne z normami cerkiewnymi. W późniejszym czasie w Tomosie patriarchy Sysaniusza z 997 roku, określono przeszkody małżeńskie. W przypadku krewnego zezwolono na małżeństwo, jedynie w VI stopniu ${ }^{34}$. W 1166 roku ustawodawstwo określiło VII stopień pokrewieństwa według krwi za przeszkodę małżeńską. Są to ramy, w których poruszało się ustawodawstwo Epiru w XIII wieku, zgodnie z opinią specjalisty od wykroczeń małżeńskich K. Pitsakisem ${ }^{35}$.

Narodziny córki w Bizancjum nie przynosiło zbytniej radości rodzicom. Wraz z nią pojawiały się zobowiązania, szczególnie uciążliwe w przypadku rodzin $\mathrm{z}$ niskimi przychodami oraz małym lub nieistniejącym majątkiem, niezbędnym do zabezpieczenia posagu córki. Rodzice mogli skierować swe dziecko na drogę małżeństwa lub życia monastycznego. Małżeństwo było naturalnym następstwem dla większości dziewcząt, zarówno z wyższych, jak również niższych klas. Pragnieniem rodziców było, zatem wydanie za mąż swych córek, aby przedłużyć ciągłość rodziny. W rodzinie rola kobiety była szczególnie decydującą i ustawodawstwo bizantyjskie usankcjonowało stosowne prawa i należną ochronę. Tym nie mniej miejsce kobiety w małżeństwie nosiło charakter, tradycyjnie niższy od tego zajmowanego przez mężczyznę. Całkowite podporządkowanie kobiety ojcowi i mężowi były cnotami, które były przedstawiane, jako ideał dobrej córki i żony. Nakaz apostoła Pawła „Żony, bądźcie uległe mężom swoim jak Panu, Bo mąż jest głową żony, jak Chrystus Głową Cerkwi, ciała, którego jest Zbawicielem” (Ef. 5,22-23) stanowił główną oś ideologii bizantyjskiej kobiecego fundamentu. Jednak w praktyce i zawsze w związku ze społecznymi osiągnięciami, kobieta bizantyjska zastrzegła sobie stanowisko różnorodne od tego ustalonego przez ideologię. Kobieta w Bizancjum rościła sobie należne prawa za pośrednictwem małżeństwa, usankcjonowanego przez prawo.

Wiek małżeński stosownie $\mathrm{z}$ prawem bizantyjskim rozpoczynał się od ukończonego dwunastego roku życia u dziewcząt i czternastego u chłopców. Małżeństwo powinno odbywać się za ich obopólną zgodą i przyzwoleniem rodziców ${ }^{36}$. Wysoka śmiertelność wśród dzieci i młodzieży

33 P. Noailles-A. Dain, Les Novelles de Léon VI le Sage, Paris 1944, nr 89,

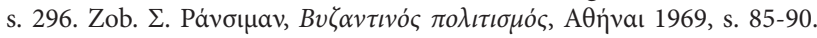
J. Meyendorff, Teologia bizantyjska. Historia i doktryna, Kraków 2007, s. 186-187. Świat Bizancjum, t. 2, Cesarstwo Bizantyńskie 641-1204, red. J-C. Cheynet, Kraków 2011, s. 354-357.

34 Г. А. Рá $\lambda \lambda \eta \varsigma$ - M. Пó $\lambda \eta \varsigma, ~ \Sigma v ́ v \tau \alpha \gamma \mu \alpha$, t. E', s. 11-19. Zob. К. Г.

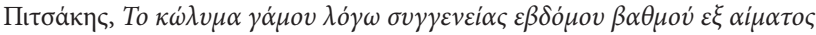

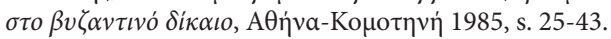

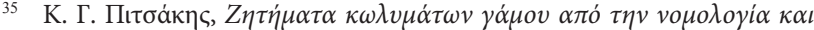

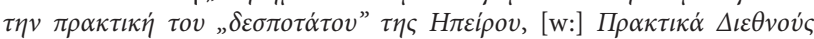

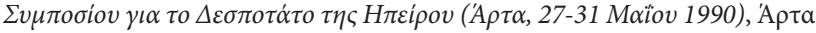
1992, s. 355-374.

36 Ecloga..., 2.1, s. 170. 
objaśnia powody tak niskiego wieku małżeńskiego, ale także starania rodziców i opiekunów do zabezpieczenia dzieci na przyszłość. Wspomniane granice wiekowe nie były zawsze stosowane. Znamy przypadki, gdy rodzice wydawali córki za mąż w niższym wieku, aby określić wcześniej los swych dzieci. Powyższe pragnienie rodziców jest widoczne

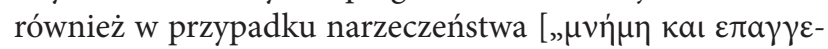

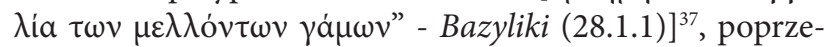
dzającego małżeństwo gdzie dopuszczano wiek siedmiu lat. Mogło mieć miejsce w formie zgody pisemnej lub ustnej między zawierającymi stronami ${ }^{38}$. W końcu IX wieku za pośrednictwem regulacji ustawodawczych Leona VI

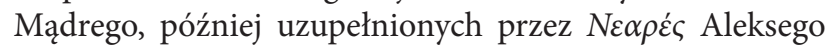
I Komnena w 1084 i 1092 roku, wyznaczono legalny wiek narzeczeństwa na 18 lat $^{39}$. Ustanowione modlitwy miały na celu nierozerwalność narzeczeństwa tak samo jak małżeństwa. Nie wykluczało to jednak możliwości zaręczenia dzieci w wieku młodszym bez czytania nad nimi modlitw

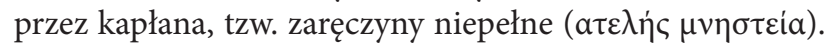
W ostatnim przypadku zabraniano wspólnego zamieszkania zaręczonych i oczywiście pozostawały w mocy wszystkie małżeńskie wykroczenia kanoniczne ze względu na pokrewieństwo ${ }^{40}$. Usakralnione narzeczeństwo nie było równoznaczne $\mathrm{z}$ małżeństwem, dlatego dzieci $\mathrm{z}$ niego zrodzone nie posiadały prawa dziedziczenia majątku ojca $\mathrm{w}$ zestawieniu ze zrodzonymi z prawomocnego związku ${ }^{41}$.

$\mathrm{W}$ praktyce nie przestrzegano przytoczonych powyżej ram ustawodawczych, jak widać na przykładzie licznych rozpraw prowadzonych $\mathrm{w}$ sądach patriarszych, ale także w biskupich sądach synodalnych, jak w przypadku tych, w których arcypasterzami byli Demetriusz Chomatenos z Ochrydy i Jan Apokaukos z Naupaktos w XIII wieku. Rodzice zaręczali córki przed ukończeniem 12 lat. Często wiązało sie to $\mathrm{z}$ zamieszkaniem narzeczonego $\mathrm{w}$ domu panny młodej, co wpływało na polepszenie finansowej kondycji rodziny. Do charakterystycznych należy zaliczyć przypadek pewnego żołnierza Bazylego Drougouwilosa, zaręczonego przez kapłana z pięcioletnią Kali, po uprzedniej umowie $\mathrm{z}$ teściem na małżeństwo, zaledwie osiągnie wiek 12 lat. Kali w miarę dorastania zaczęła okazywać niechęć wobec Bazylego grożąc w przypadku małżeństwa samobójstwem,

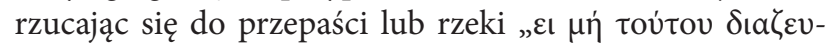
$\chi \theta$ cín”. Sąd synodalny w Ochrydzie ogłosił narzeczeństwo

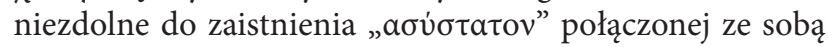
pary młodych ze względu na niedorosłość Kali a także na skutek braku zgody jednej ze stron, zgodnie z prawem. Ba-

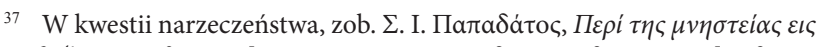

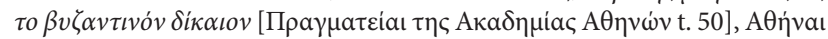

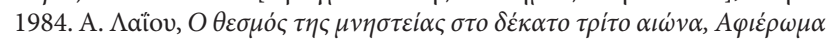

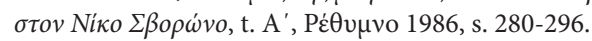

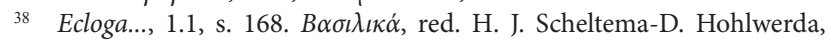
Basilicorum libri LX, Groningen 1961, 28.1.5; 28.1.12.

39 Zob. P. Noailles-A. Dain, Les Novelles..., nr 74, s. 263; nr 109, s. 355-357.

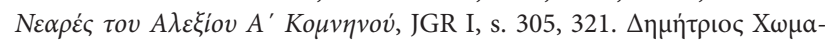

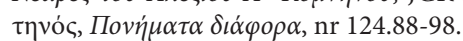

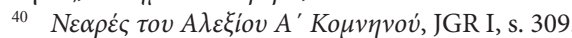

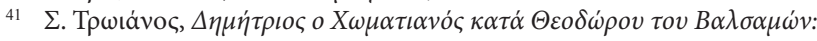

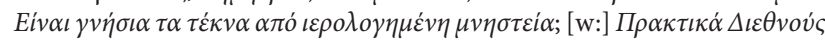

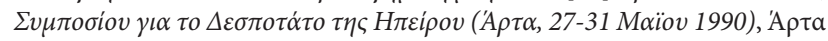
1992, s. 345-353.
}

zylemu należało zwrócić pieniądze i ubrania, które przywiózł ze sobą i zostały spisane w umowie zaręczynowej przedstawionej sądowi. Ponadto zażądał wypłacenia odszkodowania $\mathrm{w}$ postaci części dochodów z plonów za lata pracy. W rezultacie doprowadzono sprawę do względnej ugody. Wspólne zamieszkiwanie pociągało za sobą również inne konsekwencje ${ }^{42}$.

Cennymi są także dwa dokumenty metropolity $\mathrm{Na}$ upaktos Jana Apokaukosa o nielegalnej działalności sekretarza metropolii, który przyjmował łapówki za wydawanie pozwoleń na ślub, bez spełnienia kryteriów wymaganego wieku przez młodych. W rezultacie ośmioletnie dziewczyny były wydawane za mąż za dojrzałych, trzydziesto i czterdziestoletnich mężczyzn. Metropolita i synod przystąpili do unieważnienia dwóch małżeństw, które miały miejsce w Naupaktos. Apokaukos charakteryzuje wzmiankowane

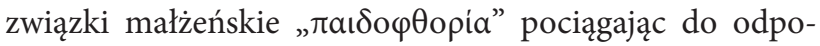
wiedzialności rodziców i sekretarza, którego pozbawił pełnionej funkcji. Od tego czasu nowożeńcy stawiali się w kolejności u metropolity i dopiero po tym przystępowano do wydania pozwolenia na małżeństwo ${ }^{43}$.

Sposób zoficjalnienia małżeństwa trwał do IX wieku. Zgodnie z ustawodawstwem Justyniańskim zawiązanie umowy małżeńskiej było obowiązkowe jedynie w przypadku wyższych rangą wojskowych, natomiast wobec pozostałych obywateli cesarstwa nie była obowiązkową żadna polityczna lub religijna ceremonia. W Eklodze Izauryjczyków

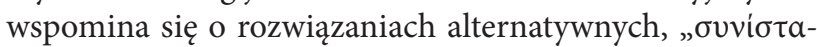

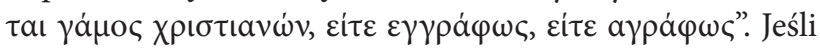
para młoda wybierała pisemne prawo, wówczas powinna sporządzić umowę posagową w obecności trzech wiarygodnych świadków. Jeśli małżeństwo nie było pisemne, wówczas wystarczała zgoda zainteresowanych i ich rodziców, aby otrzymać błogosławieństwo Cerkwi, lub oznajmić o dokonanym akcie swych przyjació $1^{44}$. We Wstępie (wczesniej w Epanagodze) z IX wieku wyznaczono rodzaje

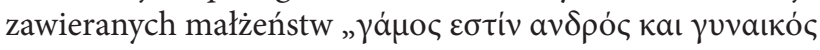

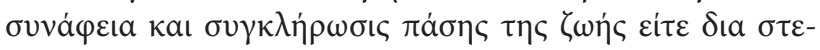

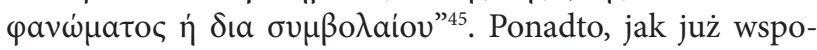
mnieliśmy, Leon VI w Nع $\alpha \rho \alpha$ 89 ustanowił obowiązkowym kryterium zawarcia związku małżeńskiego uzyskanie bło-

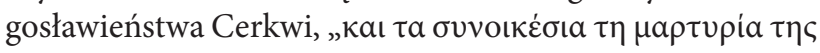

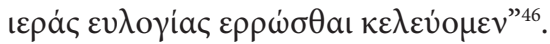

Jednym z najważniejszych celów małżeństwa była prokreacja. W celu zapobiegania tworzenia bezdzietnych związków cesarz Leon VI zabronił małżeństwa z eunucha-

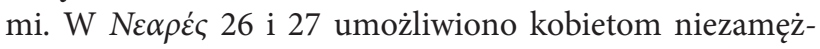
nym, a nawet eunuchom na adopcję dzieci ${ }^{47}$. Szczególny ciężar prawodawstwo położyło na przeszkody pokrewieństwa według krwi i duchowego ${ }^{48}$.

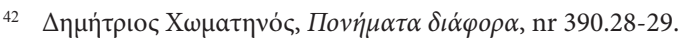

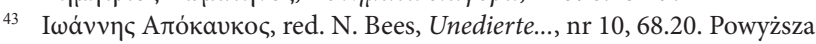
praktykę spotykamy także w innych regionach Grecji.

44 Zob. Ecloga..., 2.1, s. 170, 2.3, s. 172; 2.6, s. 178.

45 JGR 2, s. 274.

46 P. Noailles-A. Dain, Les Novelles..., nr 89, s. 296.

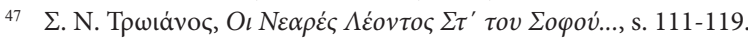

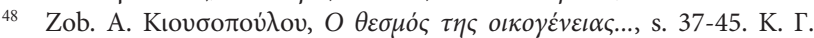

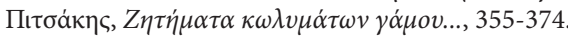


Bardziej sprawiedliwym wydaje sie pozostawać traktowanie kobiety w przypadku rozwodu. Powody rozwodu były podobne w przypadku mężczyzny i kobiety. Kobieta mogła zażądać rozwiązania małżeństwa z powodu czynu cudzołożnego męża, jeśli sprowadził do domu nałożnicę lub jeśli przez trzy lata nie spełniał małżeńskich obowiązków z powodu impotencji, choroby psychicznej lub ciągłej nieobecności. Mogła także powołać się na fakt swej niedorosłości, który w rezultacie podważał akt wspólnej zgody na małżeństwo. Niezbędnym czynnikiem było także potwierdzenie tego przez wiarygodnych świadków. Mąż mógł zażądać rozwodu $\mathrm{z}$ tych samych powodów, ponadto ze względów odnoszących się do zachowania swej żony, jeśli przebywała bez jego zgody w obecności innych mężczyzn na bankietach lub w publicznych łaźniach, jeśli odwiedzała hipodrom lub teatr lub jeśli nocowała poza swym mieszkaniem. Przytoczę charakterystyczny przypadek Ireny z Prilapy. Duchowni przybyli w roli świadków do sądu synodalnego w Ochrydzie potwierdzili, że Irena porzuciła dom małżeński i od pół roku zamieszkuje w Prilapie. Przytoczyli

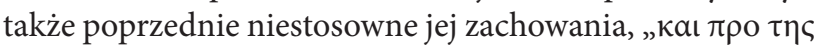

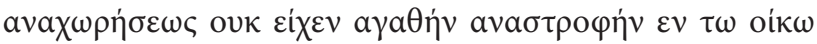

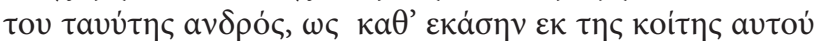

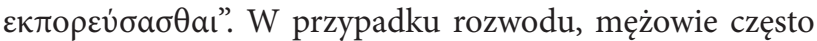

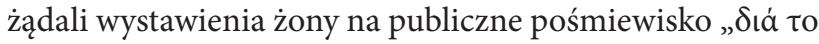

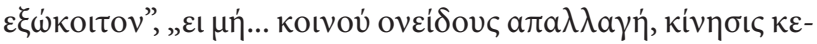

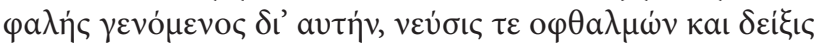

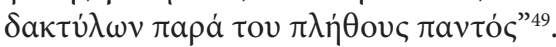

W kwestii zdrady małżeńskiej nie istniało równe traktowanie. Pozamałżeńskie związki mężczyzny z niezamężną kobietą, rozwódką lub wdową były uznane za rozwiązłość i nie stanowiły przyczyny rozwodu. Powyższą różnicę osą-

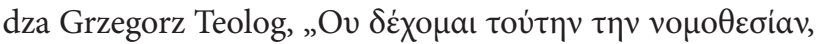

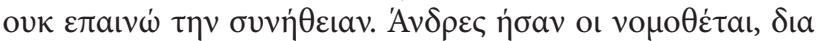

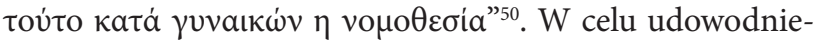
nia zdrady małżeńskiej, małżonek powinien stawić przed sąd świadków ${ }^{51}$, ale także żona posiadała prawo zażądania rozwodu, w przypadku niemożności udowodnienia z pomocą świadków winy w zdradzie małżeńskiej ${ }^{52}$. Często spotykamy świadectwa ingerencji rodziców, krewnych, sąsiadów w relacje pary młodej. Przykładem może stanowić związek małżeński Konstantego i Ireny, mieszkańców wsi Gowlace w metropolii Naupaktos, którzy byli rok po ślubie, ale nie zbliżali się do siebie na skutek nienawiści Ireny do swego męża i jej agresywnego zachowania. Na sutek usilnych próśb Konstantego Synod zdecydował przychylić się

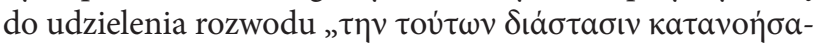

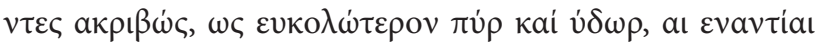

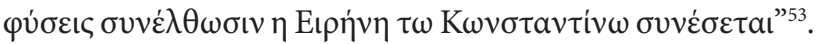

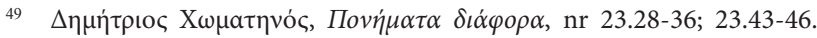

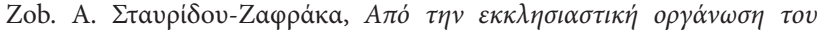

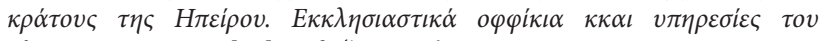

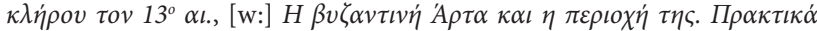

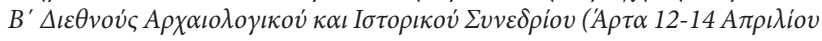
2002), AӨñva 2007, s. 161-196.

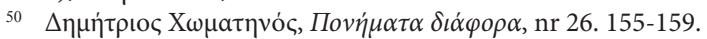

51 Ibidem, nr 127.19-24; 127.35-40;137.7.

52 Ibidem, nr 142.18-19.

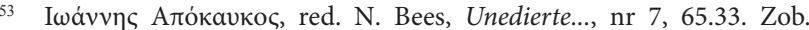

Rozwód z przyzwolenia stron istniał w Bizancjum począwszy od czasów prawa projustyniańskiego, ale pod presją Cerkwi Justynian zakazał tego typu rozwodów z jedynym wyjatkiem w przypadku wyboru życia monastycznego. Jednak wkrótce, bo przy Justynianie II powrócono do dawnej praktyki ${ }^{54}$. Natomiast bizantyjska tradycja teologiczna podkreślała całkowitą niepowtarzalność chrześcijańskiego małżeństwa. Do IX wieku Cerkiew nie błogosławił żadnego drugiego małżeństwa. Do dziś znajduje to potwierdzenie $\mathrm{w}$ fakcie, że w prawie kanonicznym zdecydowanie wymaga się tego od kleru. Możliwość rozwodu zawsze pozostawała integralną częścią bizantyjskiego prawodawstwa cywilnego. Na mocy aktu cesarskiego Leona VI Cerkiew teoretycznie zdobył formalną kontrolę nad dyscypliną małżeńską obywateli. Wiązało się to jednak z odpowiedzialnością za wszystkie kompromisy, których można było uniknąć dzięki dotychczasowej możliwości cywilnych małżeństw i rozwodów, w ten sposób Cerkiew tracił możliwość stosowania dyscypliny penitencjarnej. Od tej pory musiał, zatem rozwiązywać prawne trudności związane z rozwodami, których uprzednio udzielały jedynie sądy świeckie ${ }^{55}$.

Podstawą ekonomiczną rodziny był posag wnoszony przez pannę młodą i prezenty ślubne pana młodego. Po śmierci żony posag należał w pierwszym rzędzie do jej dzieci a w następnej kolejności do jej rodziców ${ }^{56}$. Wdowiec posiadał prawo użytkowania, jeśli nie żenił się ponownie, natomiast władza nad posagiem przynależała do dzieci. Często zdarzało się, że mąż, aby nie stracić posagu, nie wstępował w drugi związek małżeński i nie sprowadzał do domu nałożnicy. Jednak w przypadku, gdy żenił się ponownie, wówczas stawali przed sądem cerkiewnym jego dzieci z pierwszego małżeństwa $\mathrm{z}$ roszczeniami do majątku swej matki ${ }^{57}$. Posag nie mógł być odebrany dzieciom, gdyż był prawnie zabezpieczony w celu ochrony rodziny.

Podsumowując należy stwierdzić, że zarówno państwo jak Cerkiew otaczało troską instytucję rodziny. Cerkiew ze swą teologią małżeństaw i życia rodzinnego wskazuje na właściwy jej wymiar. Za pośrednictwem prawodawstwa cesarskiego i kanonów synodów starano się regulować umowy zawierania związków współżycia, kontrolowania relacji rodzinnych, nakładania ochrony na członków rodziny i głównie prawa kobiet i dzieci. Uchwały sądów synodalnych Ochrydy i Naupaktos ukazują na dobrą orientację w kwestii prawa kanonicznego hierarchów, którzy sądzili z uwzględnieniem istniejącego prawa świeckiego, ale także nakazów Pisma Świętego, teologii Pawłowej i Ojców Cerkwi. Udokumentowane uchwały, w szczególności te Demetriusza Chomatenosa, w sposób tematyczny rozpatrują różne sprawy, biorąc pod uwagę uwarunkowania społeczne epoki, ze szczególnym uwrażliwieniem na czynniki wpływające na rozwiązanie różnic i problemów rodzinnych.

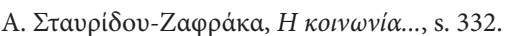

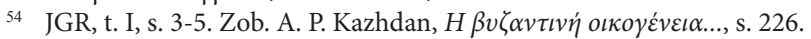

55 J. Meyendorff, Teologia bizantyjska. Historia i doktryna, s. 185-188.

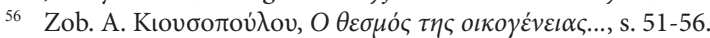

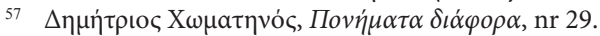




\section{Bibliografia}

Źródła

$B \alpha \sigma \iota \lambda_{\iota \kappa \alpha ́}$, red. H. J. Scheltema-D. Hohlwerda, Basilicorum libri LX, Groningen 1961.

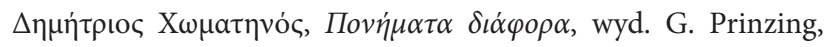
Demetrii Chomateni Ponemata diaphora [CFHB 38, Series Berolinensis], Berolini-Novi Eboraci 2002.

Ecloga. Das Gesetzbuch Leons III. und Konstantinos' V. Herausgegeben von L. Burgmann [Forschungen zur Byzantinischen Rechtsgeschichte 10].

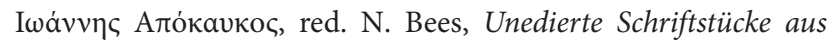
der Kanzlei des Johannes Apokaukos des Metropoliten von Naupaktos (in Aetolien), „Byzantinisch-Neugriechische Jahrbücher” 21 (1971/76) 57-160.

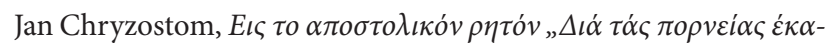

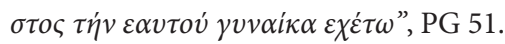

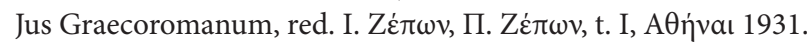

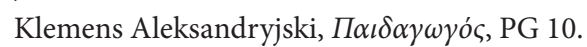

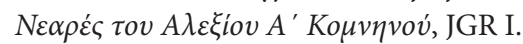

Les Novelles de Léon VI le Sage, red. P. Noailles-A. Dain, Paris 1944.

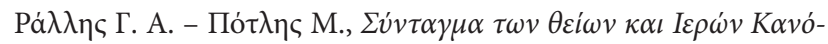

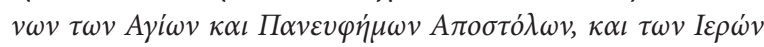

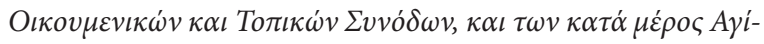

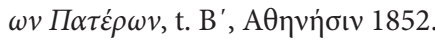

\section{Opracowania:}

Dyczewski L., Rodzina - społeczeństwo - państwo, [w:] Rodzina $w$ okresie transformacji systemowej, red. A. Kurzynowski, Suwałki - Warszawa 1995, s. 51-68.

Dziecko potrzebujące pomocy. Możliwości, kierunki, formy wsparcia $w$ środowisku lokalnym, red. J. Izdebska, Suwałki - Warszawa 2003.

Ferenz K., Wprowadzenie dzieci w kulture, Wrocław 1993.

Herrin J., Bizancjum. Niezwykłe dziedzictwo średniowiecznego imperium, Poznań 2010.

Janke A., Wychowanie rodzinne - kluczowe pojęcie pedagogicznych rozważań nad rodzina, [w:] Wychowanie w kontekście teoretycznym, red. A. Tchorzewski, Bydgoszcz 1993.

Kawula S., Brągiel J., Janke A. W., Pedagogika rodziny. Obszary i panorama problematyki, Torun 1998.

Krzesińska-Żach B., Pedagogika rodziny, Białystok 2007.

Meyendorff J., Teologia bizantyjska. Historia i doktryna, Kraków 2007.

Przecławska A., Relacje między ludźmi jako przedmiot badań pedagogicznych, Warszawa 1993.

Świat Bizancjum, t. 3, Bizancjum i jego sasiedzi 1204-1453, red. A. Laiou, C. Morrisson, Kraków 2013.

Świat Bizancjum, t. 2, Cesarstwo Bizantyńskie 641-1204, red. J-C. Cheynet, Kraków 2011.

Znosko A., Prawosławne prawo kościelne, Warszawa 1973.

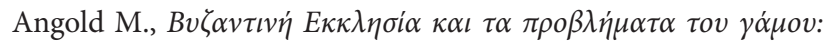

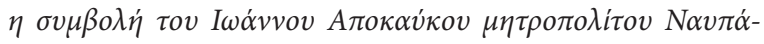

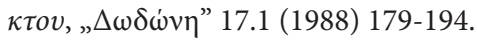

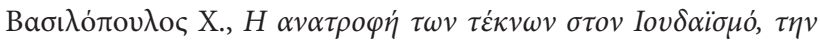

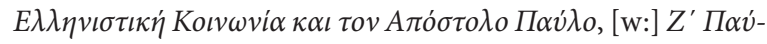

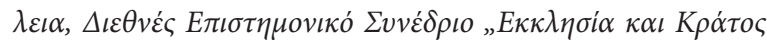

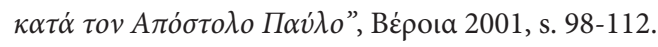

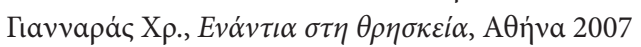

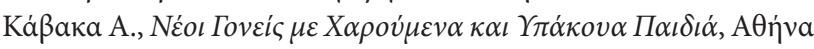
1985

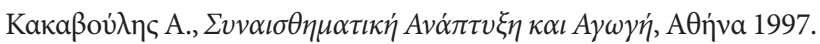

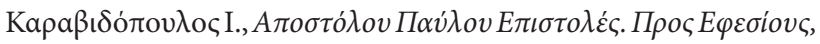

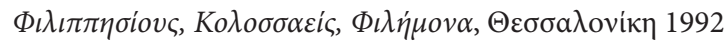

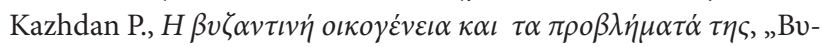

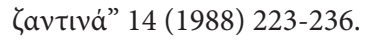

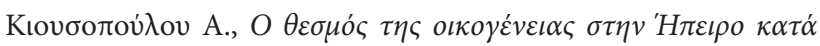

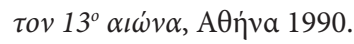

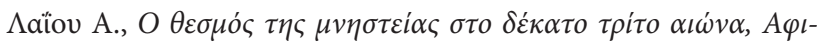

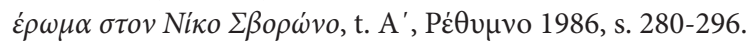

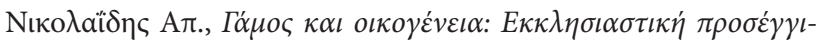

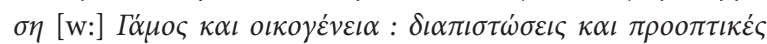

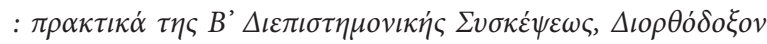

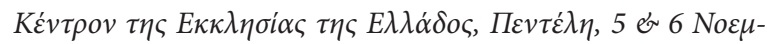

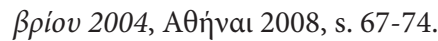

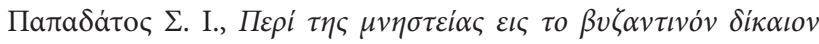

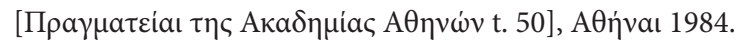

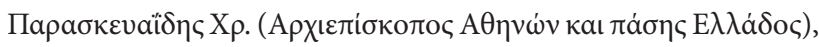

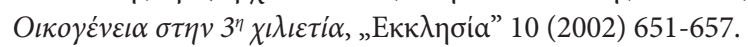

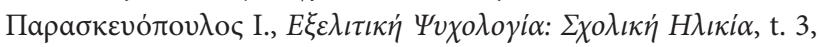
AӨñva 1985

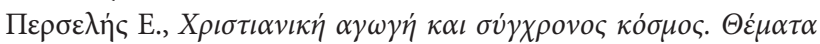

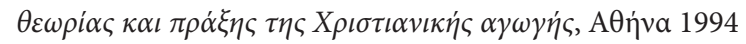

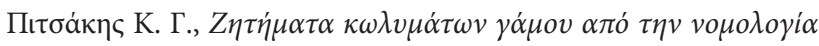

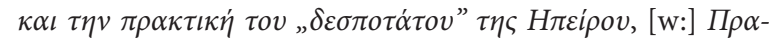

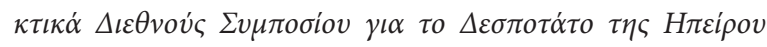

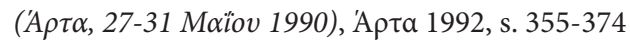

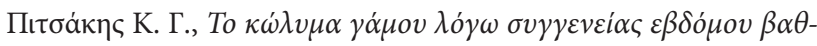

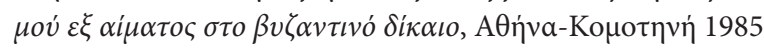

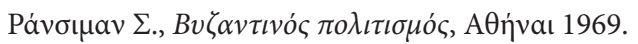

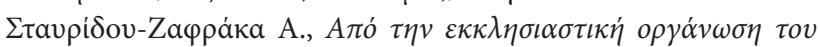

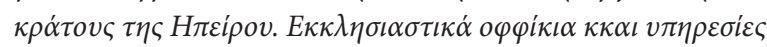

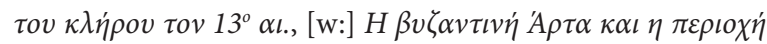

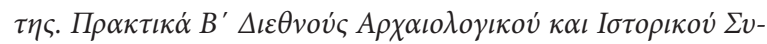

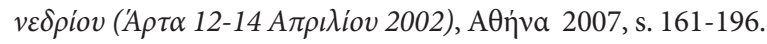

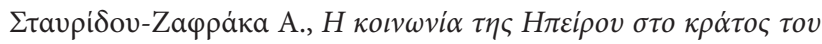

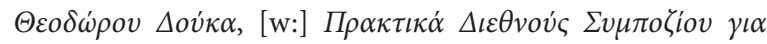

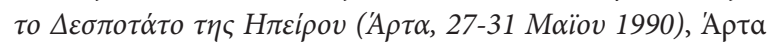
1992, s. 313-333.

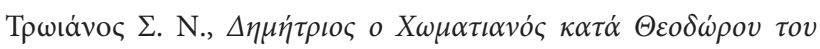

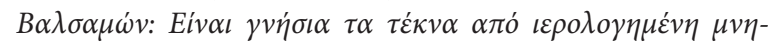

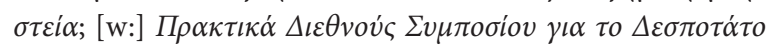

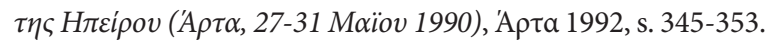

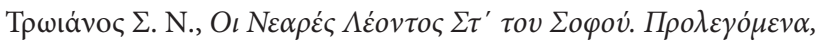

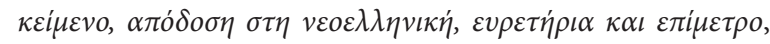
AӨjúa 2017. 